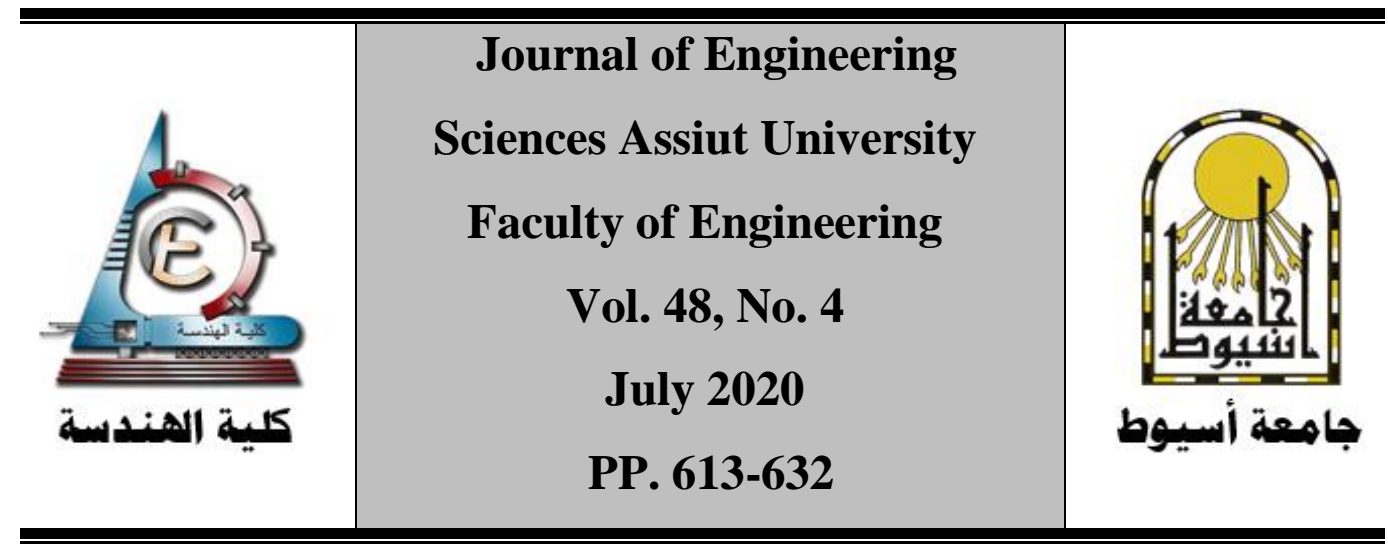

\title{
CITIES UNDER PRESSURE CASE STUDY OF NASR CITY DISTRICT - CAIRO
}

\author{
Reham M. Hafez \\ Housing \& Building National Research Center (HBRC). \\ reham_hafez@hotmail.com
}

Received

; Revised ; Accepted

\begin{abstract}
We live in a rapidly urbanizing world. In the next 30 years, 70 million people will move to urban areas every year. By 2050, two-thirds of the global population will live in cities. This rapid urbanizing, expected to continue in the coming decades, so cities face human pressure on its vital infrastructure and social care services and the natural pressure of climate change which set to intensify these existing social and economic challenges. There are physical impacts of these pressure on human health, quality of life, and business life. Therefore, most cities around the world had announced the challenges against the growth and what should be done. The research presents and analyzes the phenomena "cities under pressure" from all aspects and their impacts on citizens. Then moving to the empirical study of Nasr City, one of Cairo's districts to monitor the extent of the pressures and evaluate it to find keys guides for a comprehensive strategy with Executive steps to improve the quality of life and help for working towards sustainability.
\end{abstract}

KEYWORDS: Cities under pressure; Urbanizing; Nasr City district; population growth

\section{Introduction}

Human settlements are the result of the dynamic adaptation of the human community operating in each territory in the conditions of social, economic, and historical relations. Geographically it is the areas on which human 
settlements are located and distinguished by the apparatuses of the physicalgeographic structure, by the diversity and by the potential natural conditions, as well as by the economic and social factors in which the human settlements appear and develop [1] .It also refers to some constituents such as population, construction, markets, streets, industrial platforms, recreation, and recreation areas. It supports the unity of natural, social, material, spiritual, cultural and organizational factors, including housing, labor, energy supply, communications, water, sanitation, services, social security, administration systems, cultural facilities, recreation, etc. [2]

\section{Research Methodology}

- The study depends on the analytical approach to investigate the problem of cities under pressure.

- Related reviews of literature about cities under pressure were collected to stand on the causes and results.

- Cross-Analysis was done in the empirical study on Nasr city district to determine the challenges that face this district and conclude to a comprehensive strategy with executive steps.

\subsection{City definition}

Human settlements represent the totality of human communities, villages, towns, cities, regardless of their position, size, and functions, so the city can be defined as follow:

National definitions of cities are rarely consistent across countries and they rely on administrative or legal boundaries that do not necessarily reflect the functional and economic extent of cities. One main problem that emerges when comparing cities using national definitions is that the size of local units.[3] Administrative or legal units identifying city boundaries formally - can be starkly different across countries. Such differences potentially bias international comparative analyses through the modifiable areas' unit problem. [4]. The space covered by an area of high population density with a minimum size of the population. for the agglomeration of people in space using a consistent formula of density and total population. [5]

\subsection{Grater city}

In some cases, an urban area extended outside the boundaries of the centrallocal unit that gives it its name. This is often the case for (large) capital cities that have outgrown the small central-local unit, such as Athens, Paris, Cairo, 
and Valletta, so most of the countries added the pre-fix 'greater' is to the city name. for example, Greater London, Greater Dublin, Grand Paris, Greater Cairo, etc. often these cases have been happened due to the functional and economic extent of cities, beyond the consideration of density and population size only.[6]

The European Union or of its respective member countries considers density areas which surround the city and closely linked to its economic and functional 'Functional Urban Area' (FUA) [7].

\section{The Problem of Cities under Pressure}

The city becomes under pressure due to and human forces which cause environmental pressure. The research tries to collect the factors that make the city under pressure as follow:

\subsection{The environmental pressure}

Rising fossil fuel burning and land-use changes have emitted, and are continuing to emit, increasing quantities of greenhouse gases into the Earth's atmosphere. These greenhouse gases contain carbon dioxide (CO2), methane $(\mathrm{CH} 4)$ and nitrogen dioxide (N2O), and a rise in these gases has caused a rise in the quantity of heat from the sun suspended in the Earth's atmosphere, a heat that would normally be released back into space. This increase in heat has run to the greenhouse effect, resulting in climate change.

The main point of climate change is increasing in average temperature changes in cloud cover and precipitation particularly over land; melting of ice caps and glaciers and reduced snow cover and increases in ocean temperatures and ocean acidity [8]. Human presence has become accustomed to the variable climate around them for centuries. The effects of climate change infer that the local climate changeability that people have previously experienced and have adapted to is changing and changing at relatively great speed. Fig [1] shows Climate change as a factor of pressure on cities.

\subsection{The Dynamics of Change}

The built city has come under strong pressure due to Dynamics of Change. With far-reaching changes in the economic and demographic conditions of "urban development without growth," a new dynamic has developed for internal urban development. To hold their own in competition with others. Most cities are planning to raise their profile by improving urban stock. Local authorities focus on the strategic plan of action: developing the city centers, 
conserving historic buildings, adapting the social and technical infrastructure, fostering the residential function in inner cities, establishing and developing new educational, recreational and cultural utilities for its citizens.[9]

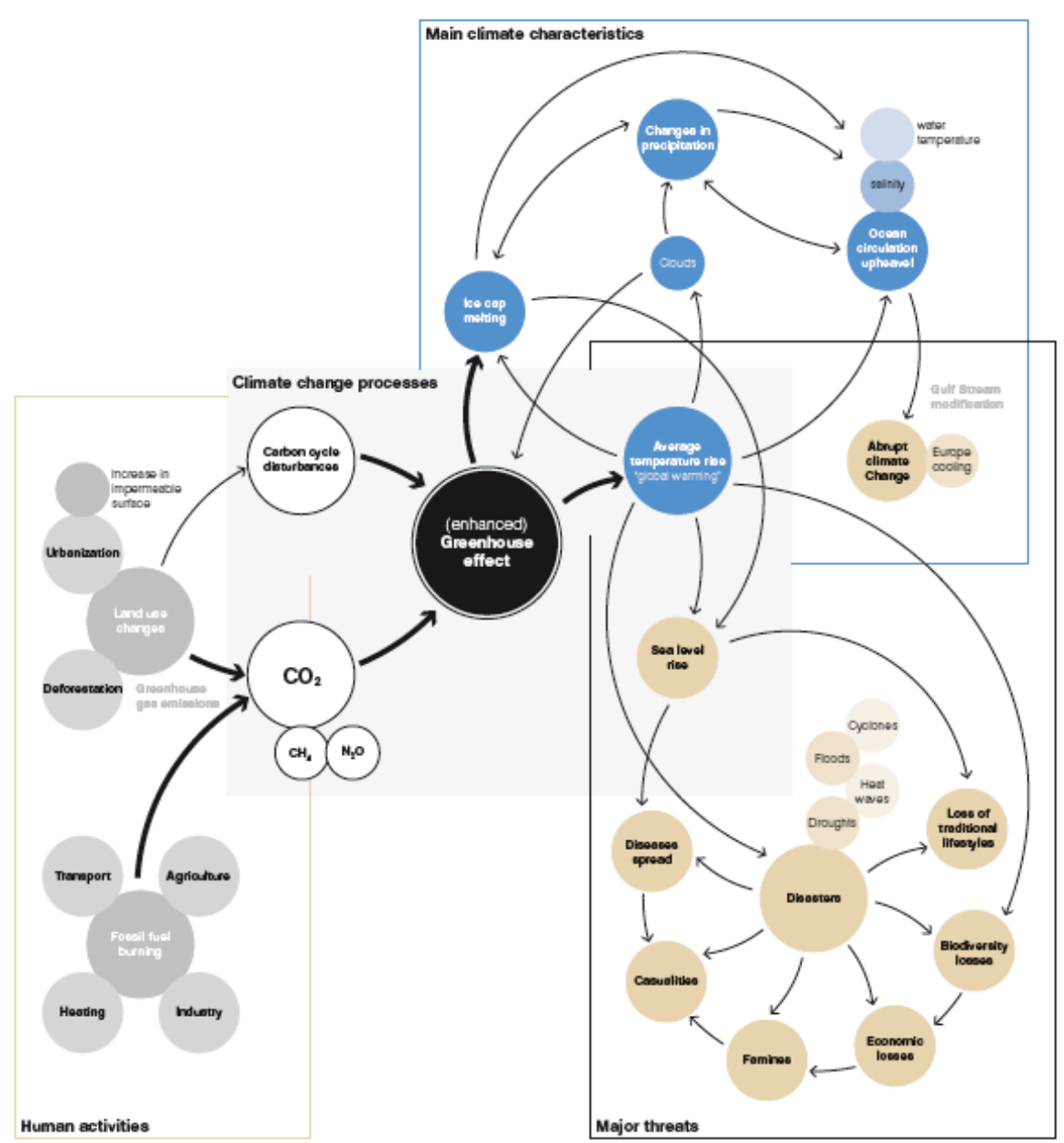

Fig (1): Climate change as a factor of pressure on cities

\subsection{Creating Housing Balance}

The policies of the governments in their countries to face the high population growth are based on increasing the housing balance and this is the basic path of development, this is done through defining variable urban determinants of population and building densities, but with the high value and scarcity of land, these determinants are not adhered to, which creates clear pressures on cities And its infrastructure of roads, services, and facilities. 


\subsection{Changes in Urban Use Structures}

Urban use structures are also coming under pressure: changes are needed to meet use demands and satisfy locational requirements. The housing situation is particularly affected by demographic developments and by changing lifestyles. Business, industry, and labor face new locational requirements, technological developments, new land resources in the city. The technical and social infrastructure has to cope with dramatic changes in population structures. Considering the previous literature, we find that the cities fell under pressure because of several clear reasons and policies arising from them by the uncontrolled mechanisms from the governments. local government is deliberately turning a blind eye to major trends because they are expected to take conspicuous effects only in the longer term (for example demographic developments), to enhance the ranks of economic cities and achieve financial returns. Fig (2) shows Cities under pressure causes \&aspects.

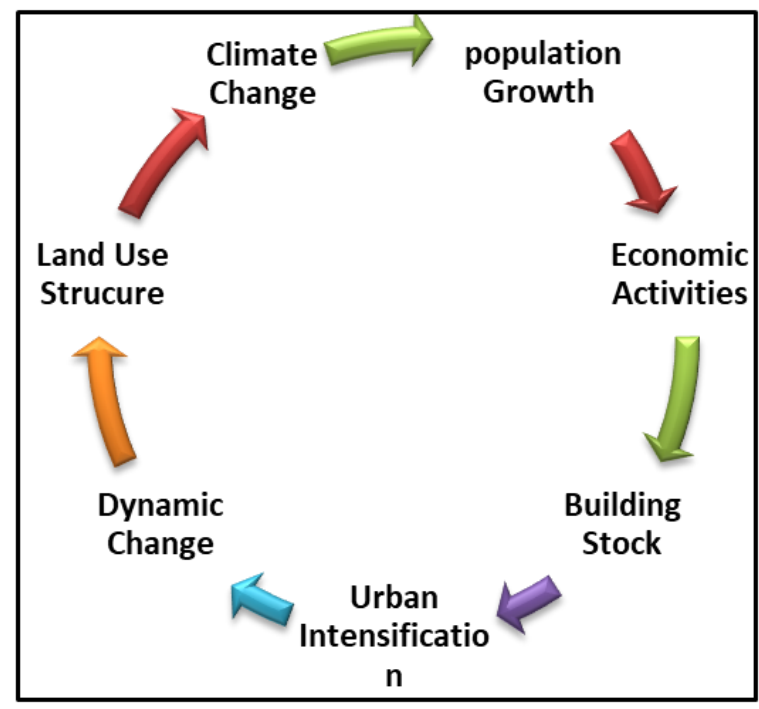

Fig (2): Cities under pressure causes \&aspects

\subsection{Example of cities under pressure around the world}

Over the last two decades, the globalization phenomenon has shaped the structure of the global economy. The liberalization of international trade, the movement of direct foreign investments, the scientific and technological progress and the upward role of international firms are the key pillars of the global economic environment, so the grater cities have large residents that make it qualified to achieve a high rank on the scale of power and influence circulation worldwide, which accordingly leads to rabid urbanism, high 
density, which had been caused a high pressure on these cities. These conditions cause the inability of cities to perform their vital functions in fulfilling the population's needs of facilities, housing, services... for example: California's recent population and job growth have outstripped its new housing production. As a result, median home prices and rents have escalated while affordability rates have fallen. Although these trends present various challenges to the state government, city governments make most of the landuse decisions that affect housing. Many observers maintain that California's cities have not done enough to accommodate new housing in recent years, and some critics have argued that local growth controls are a major cause of the state's housing shortfalls.[10] .Although the authors note that some local growth controls may definitely hinder homebuilding, they argue that extensive market forces and state policies probably do more to explain California's high housing costs and slow production. They suggest that a more predictable and transparent development process would help minimize conflict overgrowth. They also urge local officials to manage such conflicts before they erupt and to take the lead in resolving them once they do.

In Australia: Australia's largest cities are facing a watershed moment in their growth and development. In the coming 30 years, the size of the Australian population will grow substantially. Between 2017 and 2046, Australia's population is expected to increase by 11.8 million people. So, the cities will be enduring a higher density urban change. The aim of the development focused on "Future Cities Planning for our growing population" for the cities should be to deliver high-quality, higher density living, connected by good infrastructure services. Also, smaller cities, should ensure their different advantages. The opportunity exists to simplicity the pressure on the larger cities by growing the populations of the smaller ones. Delivering these solutions will require to reform how planning can administrate the cities." [11] In London: inner London's population has increased by 300,000 since 2011 to 3.5 million while Outer London's has increased by 350,000 to 5.3 million. Outer London's population is $60 \%$ of the total. These numbers are projected to grow to 3.7 and 5.6 million respectively by 2021 . The population is expected to continue growing rapidly over the coming decade, increasing by 600,000 in the six years to 2021, reaching 9.3 million. [12]

In Cairo: The high density is the focal reason for lessening the quality of urban, economic, social, and environmental conditions. It also denotes the quality of health, educational and cultural services for all groups of the society as well as the quality of transportation and the availability of public spaces and green areas, so the vision of developing the Gc defines the development opportunities of the GC for effective urban management. It aims at decreasing the necessarily growing burden resulting from the expected increase in the size and density of 
population and confirming the achievement of the community's hopes and aspirations.[13]

\subsection{The linkage between Environmental Pressure \& Human Pressure}

The Capital area that represents the center of governance and the center for all administrative services and institutions, industries, investment all human activities lead to an increase in the proportion of carbon dioxide, which contributes to an increase in pollution.

There is today a growing recognition among specialists that cities are the places where critical components of ecological modification associated with development come together. There may be sites that more directly reflect the sharpest environmental transformation, e.g. the desertification of once fertile land, but it is in cities where the multiple dynamics intersect and interact with complex multiplier effects. It is the concentration of intense economic processes and high levels of resource consumption that mark the urban condition. Unlike natural systems, cities are highly dependent on external suppliers, both natural and man-made [8].

\subsection{The linkage between pressures \& Quality of life}

The quality of life is an overarching term for the quality of the various domains in life. It is a standard level that consists of the expectations of an individual or society for a good life, so the quality of life refers to the condition of the environment that people live. There is a direct effect between pressures on cities and quality of life. Urbanism, high density, and spatial pattern of land uses are the main reason for all infancy in services \& infrastructure such as "water efficiency, transport, governmental services, energy, wastes ". All these civilized domains are directly linked with the quality of life indexes (economic - social - environmental).

\section{The Empirical Study: Case Study of Nasr City District}

Nasr City is a district of Cairo located to the east of the Cairo Governorate. It was established in the 1960s as an extension to a neighboring settlement of Heliopolis. The establishment of the district was part of the development plan to modernize and expand Cairo. From its establishment, Nasr city has a strategic plan to be a sophisticated district for the high-income level. The plan depended on a good grid street with a good urban structure. It is the largest district in Cairo, occupying nearly $250 \mathrm{~km}^{2}$ of the capital's total area of $1,445 \mathrm{~km}^{2}$. so, it is acted a $17.3 \%$ of the Cairo area. it is officially divided into 
2 districts East and West Nasr, City, for this reason, it is divided into 10 subdistricts. .[14]

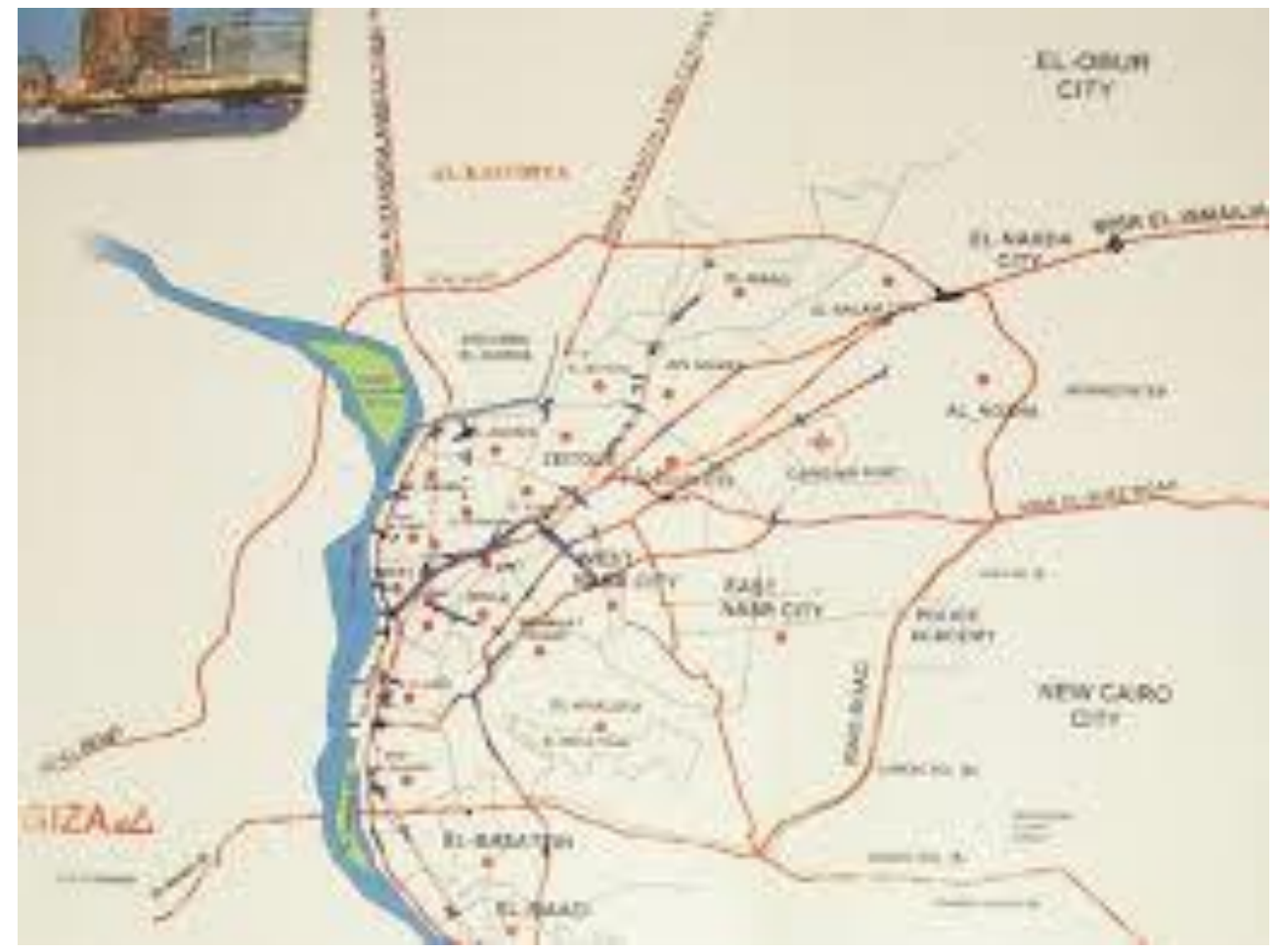

Fig (3): Nasr City District location

\subsection{The Regional Pressure}

\subsubsection{Indicators from Cairo region challenges}

Cairo governorate residents reached 9.8 million in 2019 to be ranked eighth among the world's most densely populated urban areas. (CAPMAS, 2019) [15]. Doubling in size and population between the 1950s and 2000s. The region is expected to continue growing, given the projected formal plans, the lack of control on informal urban growth, and the lack of affordable and appropriate alternatives [16]. The greater Cairo had a quality of life index 77.53 points on the global city list; much lower than its regional competitor, the City of Dubai, which has 170 points. That was due to the high congestion and pollution rates in Cairo [17] Poverty - 31\% of the population is below poverty [18], Illiteracy (15\% of the total population) [15]. Unemployment (10\% of the total labor force) [15]. The population will double within the next 40 years [14]. 


\subsubsection{The Vision of East Cairo Sector}

According to a study made by the Ministry of Housing, Utilities, and Urban Development, entitled "Urban Structure for the East Cairo Sector In 2011, the vision of the east Cairo sector was determined as follow:

- A semi-self-sufficient sector with integrated activities.

- A sector with diverse economic structures in a balanced manner.

- A source for productive values, internationally and globally.

- The study had determined the vision of Nasr city as A major Service residential area is an extension to match some limited national government services [14]

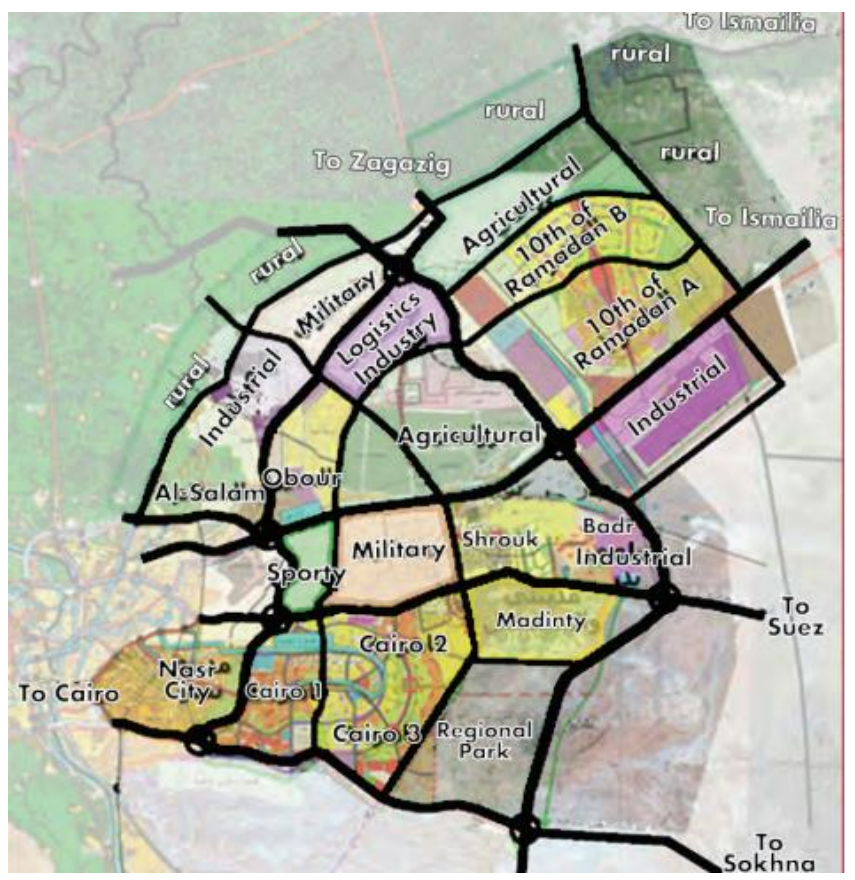

Fig (4): The Vision of East Cairo Sector

Source: Urban Restructure of East Cairo Sector In 2011

\subsection{Land uses}

There are a vital land uses like Al-Azhar University, Cairo International Stadium, the Cairo International Conference Center, many clubs, many national \& International schools, several government buildings. Many shopping malls and landmark of pyramid-like represents the Soldier Memorial. All these vital land uses made the district under pressure. Fig (5) shows land use for Nasr city district 
JES, Assiut University, Faculty of Engineering, Vol. 48, No. 4, July 2020, pp. 613-632

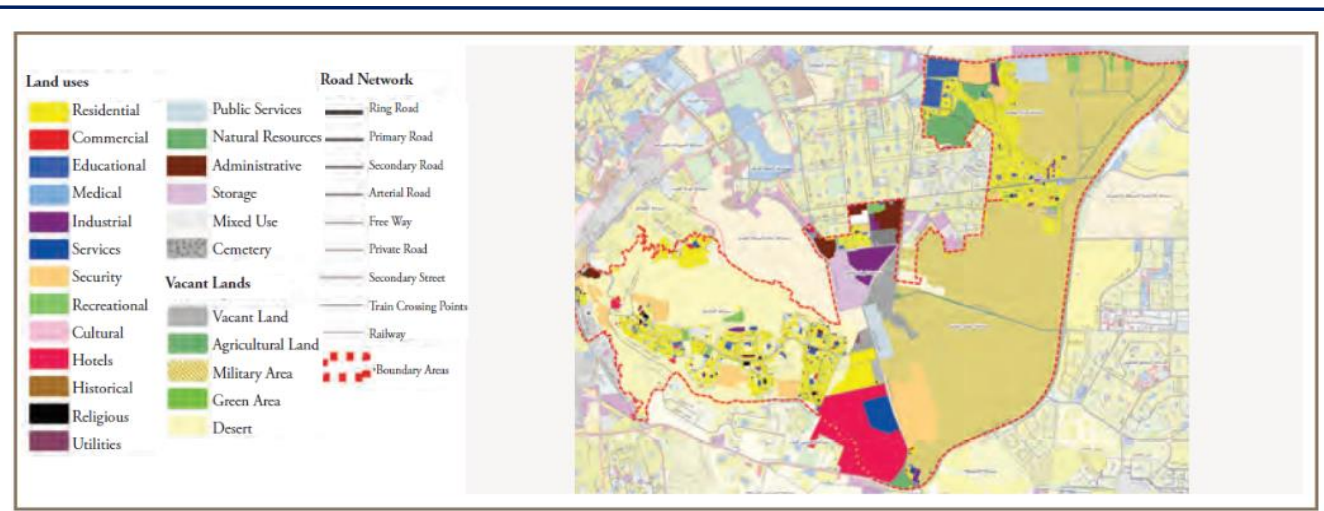

Fig (5): land use for Nasr city district

Source: Urban Structure for the East Cairo Sector In 2011

Table (1) shows the nearby land use budget 2020 according to Greater Cairo Urban Development Strategy 2012

Table (1) shows the nearby land use budget 2014

\begin{tabular}{|c|c|c|}
\hline Land Use & Faddan & $\%$ \\
\hline Planned housing & 2700.00 & $12.45 \%$ \\
\hline Unplanned housing & 504.00 & $2.32 \%$ \\
\hline Industrial & 811.00 & $3.74 \%$ \\
\hline Commercial & 2246.00 & $10.35 \%$ \\
\hline Administrative & 1863.00 & $8.59 \%$ \\
\hline Security & 8517.00 & $39.26 \%$ \\
\hline Cemeteries & 298.00 & $1.37 \%$ \\
\hline agricultural & 247.00 & $1.14 \%$ \\
\hline Vacant Land & 2971.00 & $13.70 \%$ \\
\hline Other & 1101.00 & $5.08 \%$ \\
\hline Total & 21692.00 & $100.00 \%$ \\
\hline
\end{tabular}

Source: Greater Cairo (GC), Urban Development Strategy, Part I: Future Vision and Strategic Directions, 2012,

The table shows:

- A big percentage of security land inside and outside the urban mass, which transform step by step to residential and commercial uses. this acts as a continuous \& dynamic change in the district's structure.

- Unplanned housing of Ezbat Elhaggana which occupies $2.3 \%$ of the district's area. 


\subsection{Housing levels}

According to a study of restructuring the east sector of Cairo (2011) [14], the housing levels of Nasr city consist of $20 \%$ economic housing, $40 \%$ moderate housing, $20 \%$ up moderate, $20 \%$ luxury housing. In addition to the informal housing in ezbat elhaggana.

\subsection{Economic Activities}

Nasr City has a large concentration of shopping malls (Genena Mall, Tiba Outlet Mall, City Center, Serag Mall, City Stars, Suncity Mall ), One of the main reasons for the success of these commercial centers is the simple grid roads of Nasr City. Another concentration of different trade activity in the main streets (Abbas El-Akad, Makram Ebeaid, Mostafa El-Nahas)

\subsection{Pressure causes, aspects, results}

In the next part, the research identifies and monitors the causes, aspects, results that put Nasr city district under pressure. It is the first step towards formulating a vision and developing a strategic plan that meets the population's needs.

\subsubsection{Pressure (1): link Location between new Cairo city and old Cairo} There are main factors of making the district under pressure according to its location:

1. Nasr City district is the link between, the city of New Cairo and the new administrative capital from its east and the old Cairo from its west. Several roads and axes have been relied on to link these cities together such as "El-Mosher axis, El-Waha axis, "

2. To achieve balance and integration between the economic activities and housing levels in Nasr City, which is distinguished in the New Cairo.

3. Ongoing and Proposed Main way Lines:

- The fourth line of underground metro was planned to link 6 October city with New Cairo city passing through Nasr city district.

- Another main way line "Monorol " has been proposed with a plan to connect Line 3 with Line 4 through a route which is mostly parallel to the Ring Road's eastern arc, therefore covering New Cairo from north to south starting at the Cairo International Airport and ending at the beginning of the Cairo-Ain Sokhna Highway. 
New Cairo \& New Capital Map

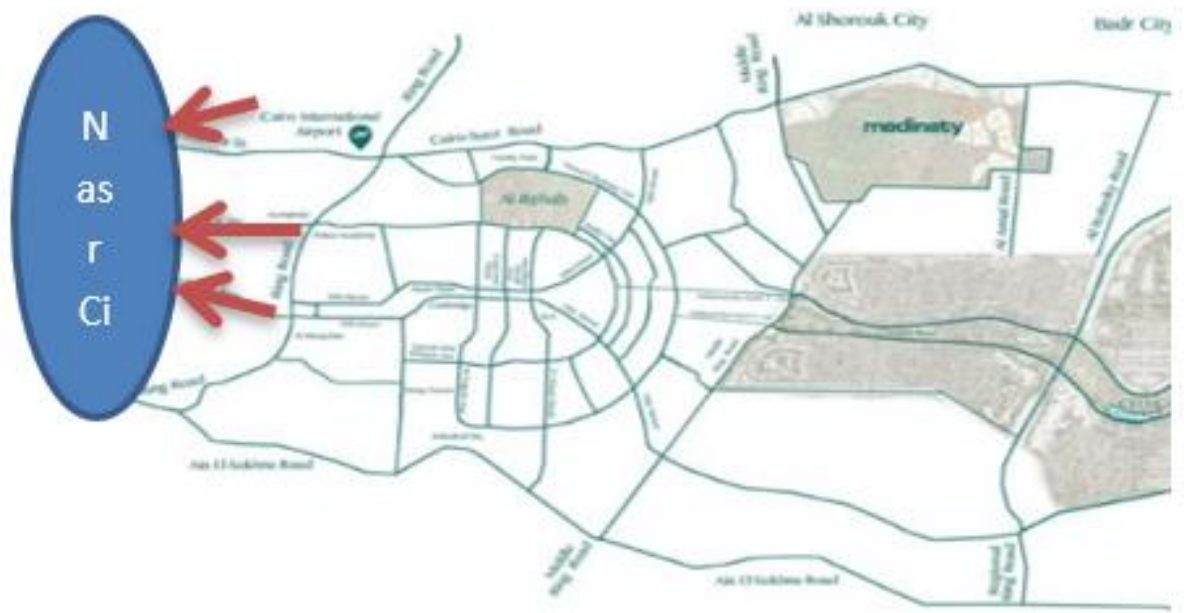

Fig (6): Main axis between Nasr city and new Cairo

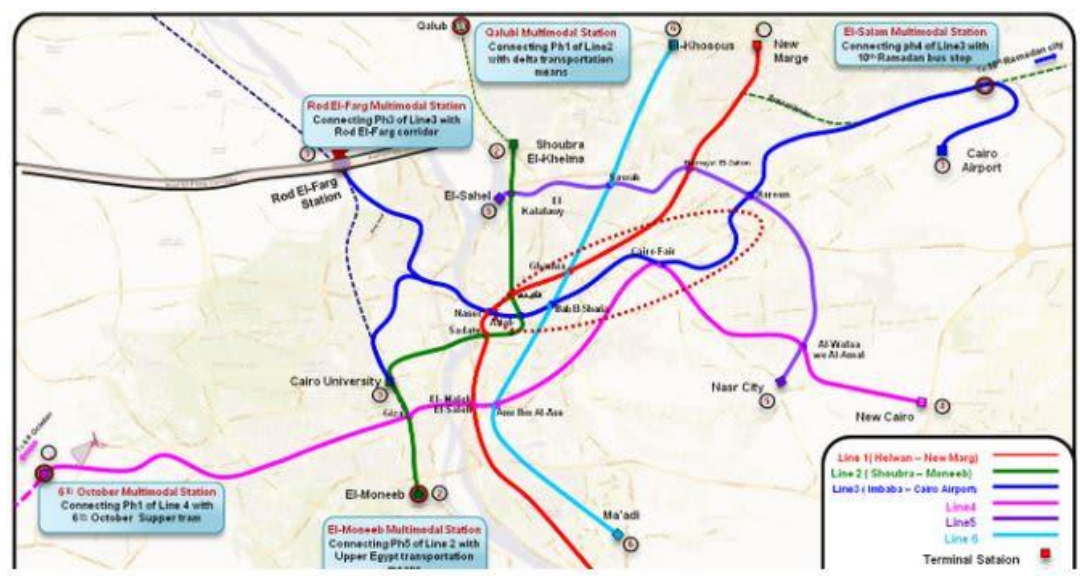

Fig (7): Proposed path for underground metro line 4

\subsubsection{Pressure 2: International \& Local Immigration}

1. Al Azhar University is one of the important universities in the Islamic world, students come to learn from all Arab countries, this cause many nationalities leave in Nasr city like Somali and South Sudanese in El-Hay El Asher.

2. Due to the location of the district as a border community on the outskirts of the Greater Cairo Region, it witnessed internal migration from Delta and the Suez Canal governorates. 


\section{5}

Reham M. Hafez., Cities Under Pressure Case Study of Nasr City District - Cairo

\subsubsection{Pressure 3: special pattern of land uses}

The regional and international uses, such as the exhibition land, Cairo stadium, conferences hall and international park, are considered a mega open space inside Nasr city district which reduce density in general but on the other hand, it represent pressure on Nasr City district in light of the presence of permanent events in these places, for example, the visitors of annual book fair to the book fair in 2018 exceeded 3.7 million in 11 days" .Many events are held in this international and regional uses permanently.

\subsubsection{Pressure 4: Urban Growth}

Fig (8) explains the District Rapid Extension from 1999 to 2019. The figures show a big extension in the high areas. The extension areas between 1999: 2009 around 700 faddan. The extension areas between 2009: 2019: around 1300 faddan.

\subsubsection{Pressure 5: Unplanned Growth of Ezbat El-Hagana}

Ezbet al Haggana, is one of the mega informal area in Cairo, where squatters of nomadic Arab origin from the northeastern governorate of Sharkiya settled in a pocket within military land along the Cairo-Suez regional road .Given its illegal status, deprived of all forms of infrastructure or services, isolated and difficult to access except a single controlled entrance, this area attracted more groups who seek refuge such as those escaping from criminal charges in Upper Egypt. Although many people from al-Haggana work in the adjacent Nasr city (as security personnel in housing blocks or domestic help). [19]

Since the beginning of the 2000s, Ezbet El-Hagana had witnessed an unprecedented urban intensification, where the small buildings and the twenties that were established in 1980s, from 1990s replaced with a huge residential towers exceeding ten floors, which led to increasing its population to at least ten times ( there are no documented numbers about the population ) In 2020, The area of Ezbet El-Hagana exceeded 625 faddan. (Google Earth 2020). Its population is more than 600 thousand people with a population density about 1000 people / feddan with a site index of $80 \%$.

Cairo governorate tried to clear some parts in 2000 and 2009 but with no success because it had faced a massive obligation from vast numbers of inhabitants. 
1999
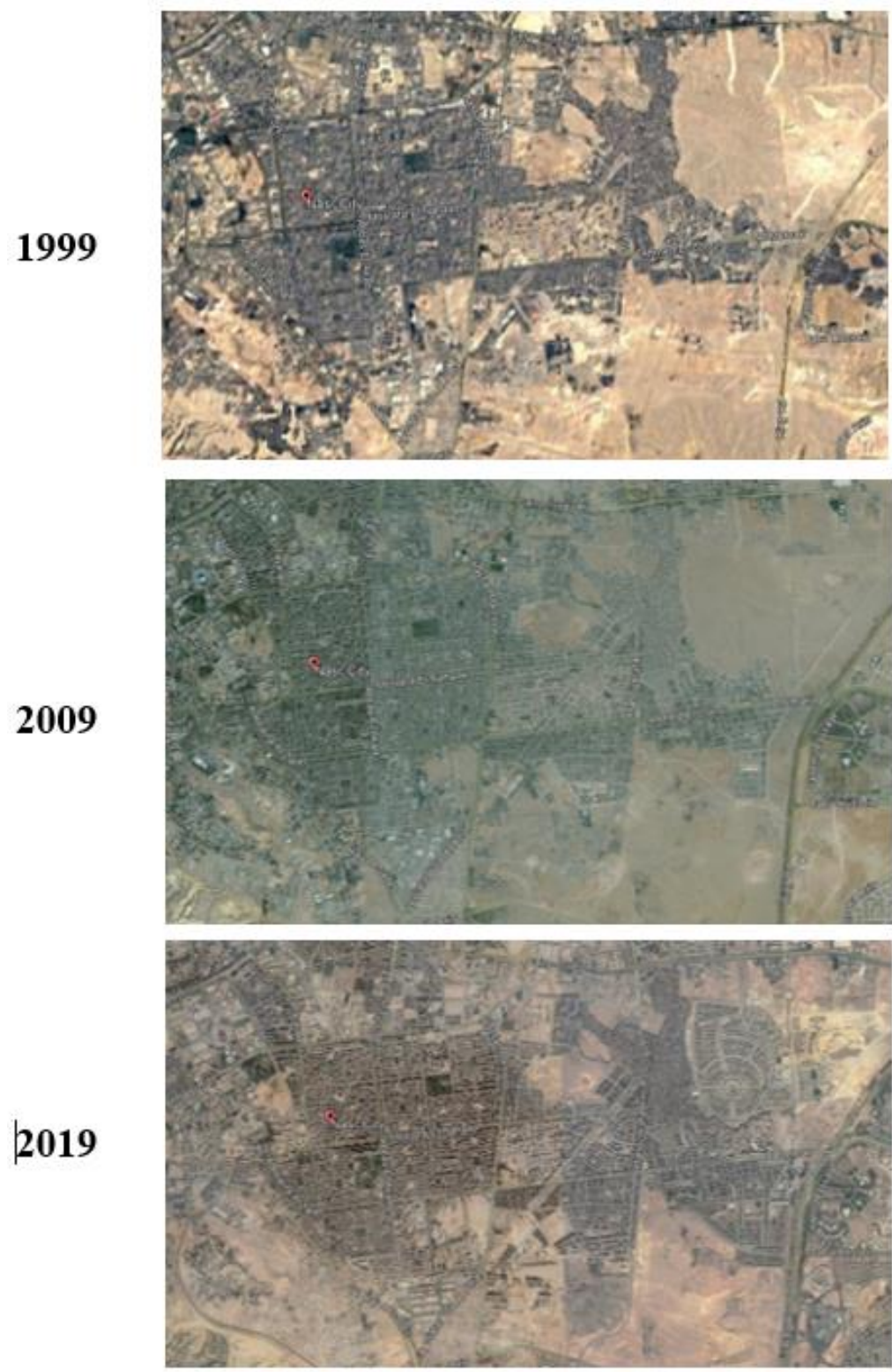

Fig (8): Nasr City urban mass 1999, 2009, 2019

\subsubsection{Pressure 6: Informal trade activities:}

a vacant area located under the high electric line used as a gathering point of trade of used cars from all Egypt governorates. This situation has caused hundreds of car merchants to immigrate to Nasr City from all governorates. This regional market makes Traffic crisis on Friday every week in all surrounding roads. Floors of the surrounding buildings had transformed into cafeterias and car-related activities. Fig (12) shows Informal trade activities 


\section{7}

Reham M. Hafez., Cities Under Pressure Case Study of Nasr City District - Cairo
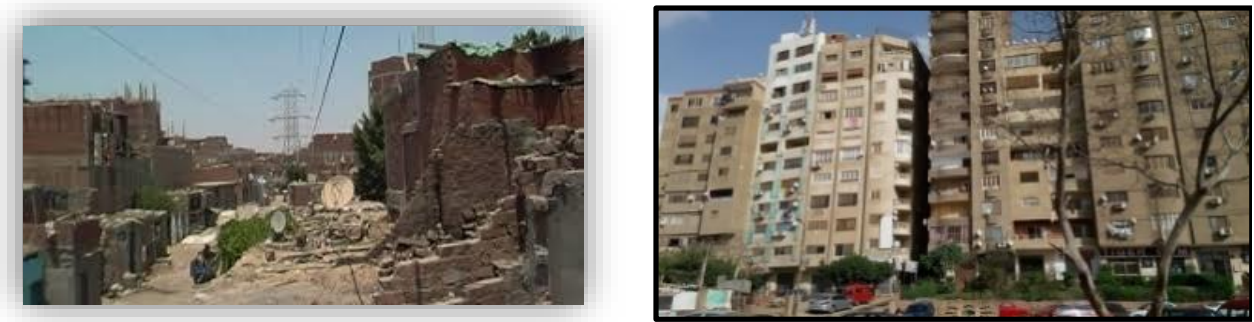

Fig (9): Unplanned Growth of Ezbat El-Hagana 1999 ,2019

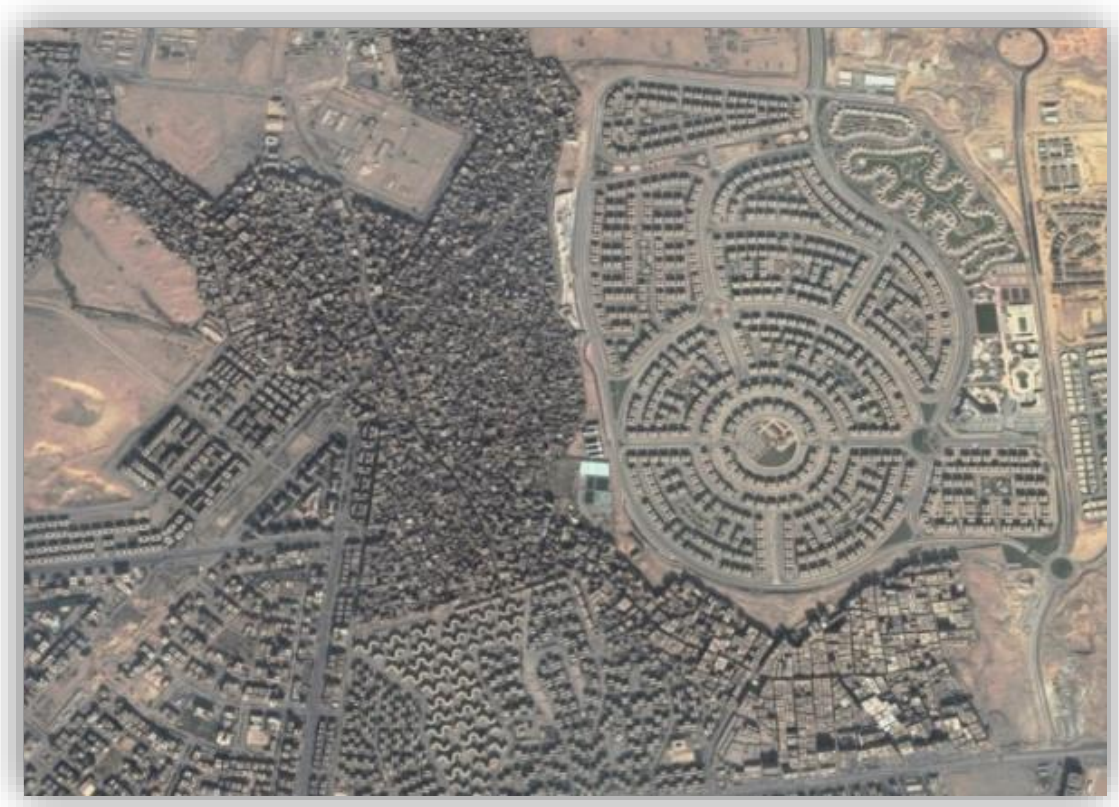

Fig (10): Unplanned Growth of Ezbat El-Hagana touching the luxury housing

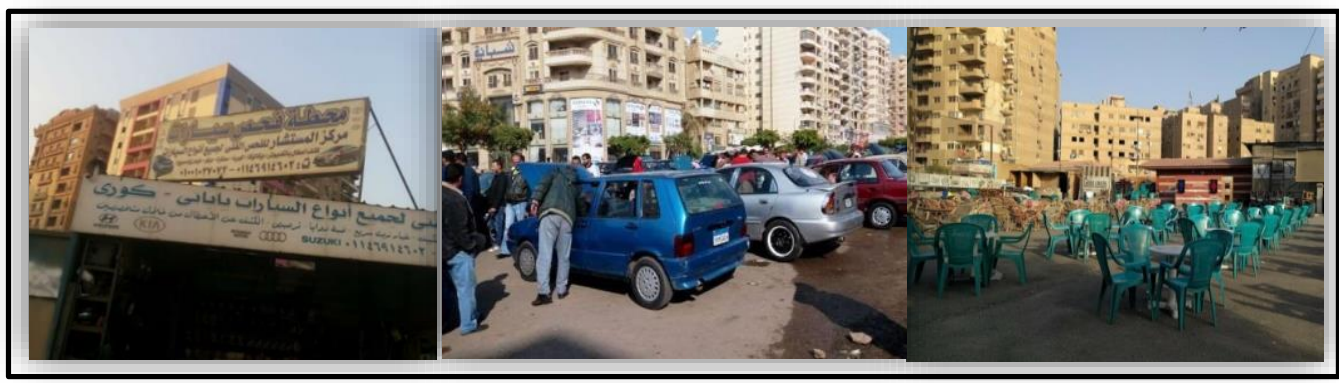

Fig (11) Informal trade activities 


\subsubsection{Pressure 7: Intensification of Economic activities:}

Trade is a significant source of attraction to Nasr city district: In the main streets (Abbas El-Akad - Makrem Abied - El-Nozha - Mostafa El-Nahas) most of the building floors transferred to commercials. In the secondary streets, nearly all the ground and first floor in all residential buildings transferred to commercial uses. All clubs' walls and fences are the same cases. Fig (11) shows Intensification of Economic activities

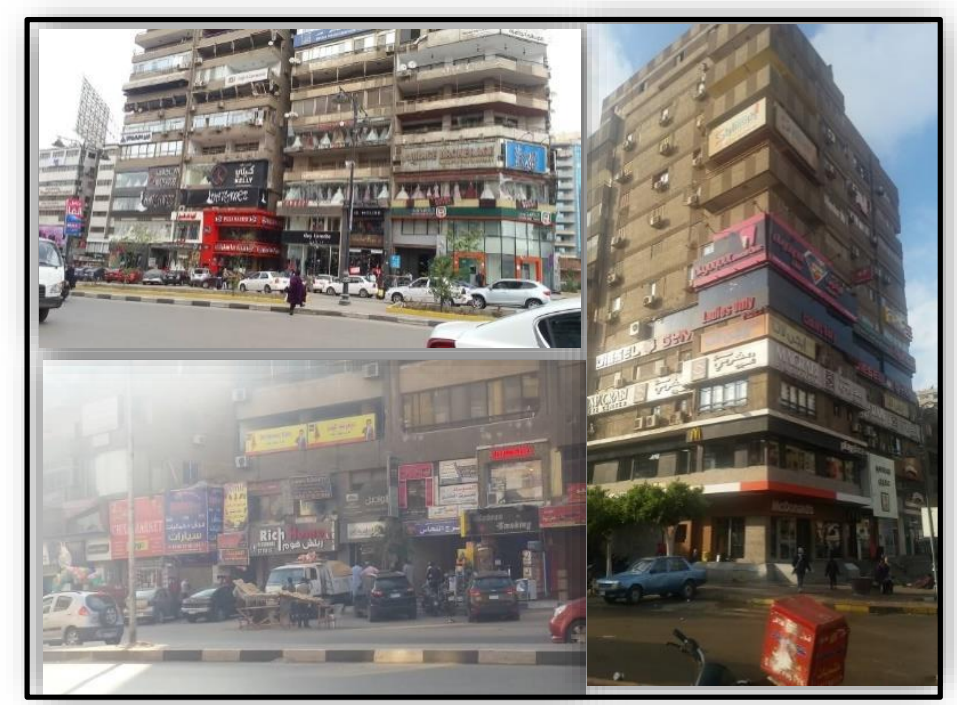

Fig (12): Intensification of Economic activities

\subsubsection{Pressure 8: Lack of green areas on main roads}

To deal with the traffic jam, the central islands have been removed from the roads, which cause a lack of green path from the roads, Fig (13) shows lack of green path from the roads

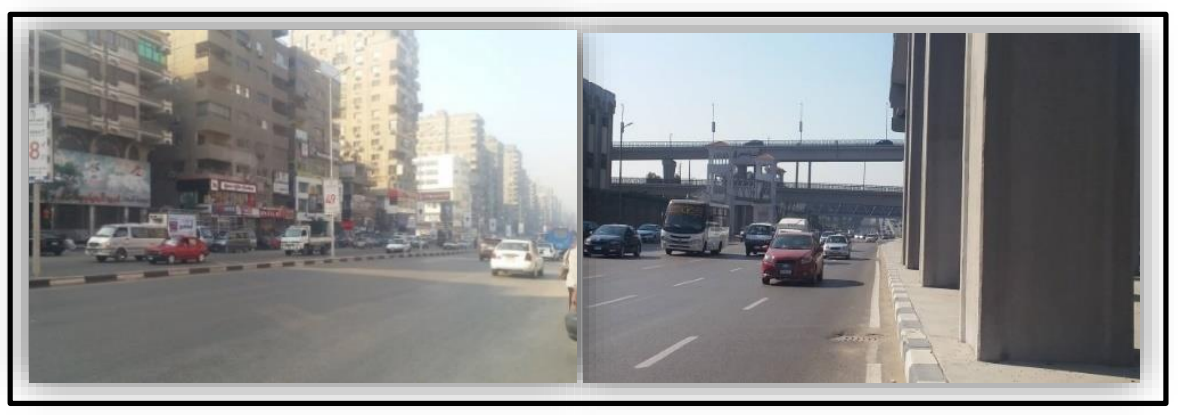

Fig (13): Lack of green areas on main roads 


\subsubsection{Pressure 9: Road\& sidewalk encroachments:}

Fig (14) shows the Examples of encroachments and road violations

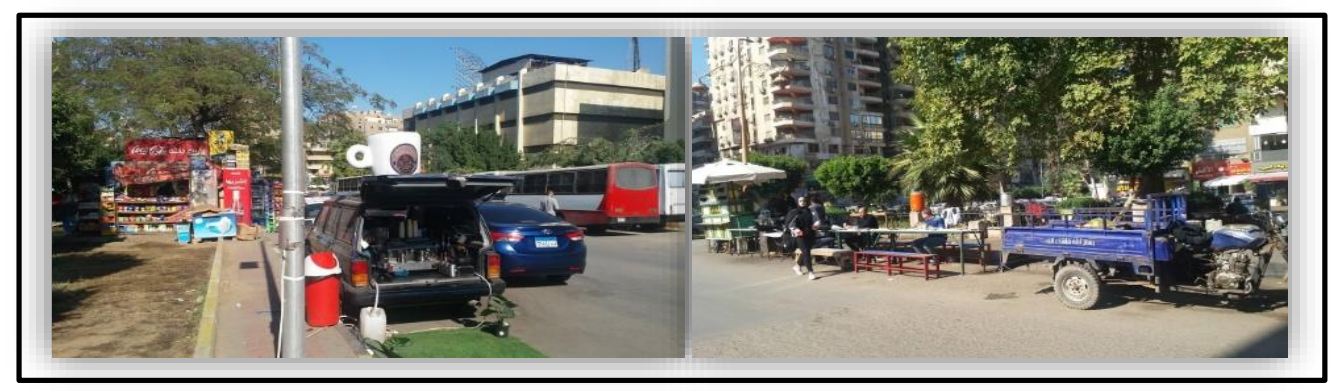

Fig (14): Examples of encroachments and road violations

\subsubsection{Pressure 10: Streets Slops:}

As a result of streets slops, some areas of the district are drowned with water during the rains than others, this leads to the accumulation of rainwater in the low levels areas, which causes malfunction traffic, damages in the buildings ground floors.

Table (2) SWOT Analysis for the existing case in Nasr City District

\begin{tabular}{|c|c|}
\hline Strengthens & Weakness \\
\hline $\begin{array}{c}\text { Vital location. } \\
\text { Good urban structure. } \\
\text { Good street network. }\end{array}$ & $\begin{array}{c}\text { Defective laws. } \\
\text { Bad administrative system. } \\
\text { Informal area of about 650 feddan. }\end{array}$ \\
\hline Opportunities & Threats \\
\hline $\begin{array}{c}\text { Vacant land of security \& armed } \\
\text { force camps about 300,000 } \\
\text { feddan. }\end{array}$ & $\begin{array}{c}\text { High land prices, rents. } \\
\text { existing high-density }\end{array}$ \\
\end{tabular}

\section{Results}

According to the previous analytical study that had analyzed the pressures on Nasr City district, the research had summarized the main aspects that cause the pressure:

- population growth with high density.

- centralization of Commercial, offices, and services.

- Unplanned areas (Ezbat El-hagana) with uncontrolled extension.

- No control over changing residential uses to administrative and commercial.

- Very high density in some neighborhoods. 
These results caused to make over the district from a high-end district to an unregulated and uncontrolled structure in the recent years, which make the population dissatisfied with the level of services provided to them and a lack of realization of the ambitious quality of living who responded to it for a realization, which prompted some original people to relocate outside the district to the New Cairo that provided a better quality of living. A SWOT analysis was done to elaborate on this case as a key guide for these challenges.

Table (3) comprehensive development policy through specific programs and projects .

\begin{tabular}{|c|c|c|c|c|c|}
\hline Tools & \multicolumn{2}{|l|}{ Goals } & \multicolumn{2}{|c|}{ Program } & Projects \\
\hline \multicolumn{6}{|c|}{ Improving residents' living conditions and quality of life } \\
\hline \multirow[t]{2}{*}{$\begin{array}{c}\text { Urban } \\
\text { Development } \\
\text { and Land Use }\end{array}$} & $\begin{array}{l}\text { Reduce high } \\
\text { population } \\
\text { attraction. }\end{array}$ & \multicolumn{2}{|c|}{$\begin{array}{l}\text { Reduce } \\
\text { centralization } \\
\text { of commercial } \\
\text { stores, offices, } \\
\text { and services }\end{array}$} & \multicolumn{2}{|c|}{$\begin{array}{l}\text { Move used car market to the vacant } \\
\text { land of security \& armed force camps outside } \\
\text { the current urban mass. } \\
\text { Using vacant land of security \& } \\
\text { armed force camps as an alternative land for } \\
\text { the conglomerate's Commercial activities. } \\
\text { Setting specific conditions, } \\
\text { Controlling, and lessening changing } \\
\text { residential uses to administrative and } \\
\text { commercial. } \\
\text { needed trade activities in the urban mass. }\end{array}$} \\
\hline & $\begin{array}{l}\text { Prevent } \\
\text { extension of } \\
\text { ezbat } \\
\text { Elhagana. }\end{array}$ & \multicolumn{2}{|c|}{$\begin{array}{l}\text { Dealing with } \\
\text { unplanned } \\
\text { areas (Ezbat } \\
\text { El-hagana) }\end{array}$} & \multicolumn{2}{|c|}{$\begin{array}{c}\text { Starting the urban renewal policy to develop } \\
\text { Ezbat El-hagana concerning its surrounded } \\
\text { neighborhoods and using the vacant land to } \\
\text { overcome obstacles which faces urban } \\
\text { renewal process. }\end{array}$} \\
\hline \multicolumn{6}{|c|}{ Promoting environmental conditions and achieving sustainability } \\
\hline $\begin{array}{l}\text { The stock of } \\
\text { open spaces }\end{array}$ & \multicolumn{2}{|c|}{$\begin{array}{l}\text { Providing a clean } \\
\text { healthy } \\
\text { environment } \\
\text { and achieving } \\
\text { sustainable } \\
\text { development }\end{array}$} & \multicolumn{2}{|c|}{$\begin{array}{l}\text { Adopting a } \\
\text { strategy for } \\
\text { addressing } \\
\text { pollution issues } \\
\text { and } \\
\text { its causes }\end{array}$} & $\begin{array}{l}\text { Using the vacant lands of security \& } \\
\text { armed force camps as green spaces. } \\
\text { Preserve the existing public open } \\
\text { spaces. } \\
\text { Establishing integrated systems for } \\
\text { solid waste management using the } \\
\text { huge district budget. }\end{array}$ \\
\hline \multicolumn{6}{|c|}{ Enactment of new administrative policy for Cairo urbanism. } \\
\hline $\begin{array}{l}\text { Effective } \\
\text { governance } \\
\text { system }\end{array}$ & $\begin{array}{r}\text { Control rar } \\
\text { growth } \\
\text { extensions } \\
\text { units us } \\
\text { change }\end{array}$ & & $\begin{array}{r}\text { Reviey } \\
\text { legal s } \\
\text { changi } \\
\text { from resi } \\
\text { others }\end{array}$ & $\begin{array}{l}\text { us the } \\
\text { us of } \\
\text { uses } \\
\text { ential to } \\
\text { ses. }\end{array}$ & $\begin{array}{l}\text { Using smart systems to improve } \\
\text { quality of life in infrastructure, } \\
\text { services, and transport systems. } \\
\text { Providing local units with an } \\
\text { Effective governance system. } \\
\text { Stop all illegal changes and } \\
\text { encroachments. }\end{array}$ \\
\hline
\end{tabular}




\section{References}

[1] Amjad Almusaed \& Asaad Almssad, (2018), Introductory Chapter: Overview of Sustainable Cities, Theory and Practices publication.

[2] Department of Environmental Management and Toxicology, UNAAB, (2011), Abeokuta Human Settlement and Development (EMT 506).

[3] OECD, (2012), Redefining "Urban" A New Way to Measure Metropolitan Areas.

[4] Openshaw, S, (1976), "An empirical study of some spatial interaction models" Environment and Planning. Pion Ltd, London

[5] Eurostat (2018), Methodological manual on territorial typologies. 2018 edition. Publication Office of the European Union, Luxembourg. https://ec.europa.eu/eurostat/documents/3859598/9507230/KS-GQ-18-008-EN-N.pdf -en

[6] Openshaw, S. (1977), "Optimal zoning systems for spatial interaction models", Environment and Planning, Vol. A9, pp. 169 - 184. OECD (2012), Redefining "Urban": A New Way to Measure Metropolitan Areas, OECD Publishing. http://dx.doi.org/10.1787/9789264174108

[7] Lewis Dijkstra, Hugo Poelman and Paolo Veneri, (2019) THE EU-OECD DEFINITION OF A FUNCTIONAL URBAN AREA.

[8] United Nations Framework Convention on Climate Change UNFCCC CLIMATE CHANGE: IMPACTS, VULNERABILITIES AND ADAPTATION IN DEVELOPING COUNTRIES

[9] Häußermann 2003a; DST 2003a,b Urban Development and Planning in the Built City: Cities under Pressure for Change, (2015), German Institute for Urbanites. https://difu.de/publikationen/urban-development-and-planning-in-the-built-citycities.html

[10]Paul G. Lewis \& Max Neiman, (2002), Cities Under Pressure: Local Growth Controls and Residential Development Policy, Public Policy Institute of California.

[11]Australia Infrastructures, (2018), Future Cities Planning for our growing population. Reform Series publications.

[12]The 2013 London Strategic Housing Market Assessment Part of the evidence base for the Mayor's London Plan.

https://www.london.gov.uk/file/15571/download?token=q4aeX4gP"

[13]Development Programmed (UNDP). (2012), Greater Cairo Urban Development Strategy Part I: Future Vision and Strategic Directions,

[14]General Organization for Physical Planning, New Urban Communities Authority, (2011), Urban Restructure of East Cairo Sector.

[15]Central Agency for Public Mobilization and Statistics. https://capmas.gov.eg

[16]Randa A. Mahmoud \&Ahmed S. Abd Elrahman, (2016), Social Production of Urban Space in Informal Areas in the G.C.R "Missing Values \& Probable Potential. https://link.springer.com/chapter/10.1007/978-3-319-29948-8_7

[17]Report of the Global City Index 2019," https://www.kearney.com/global-cities" line Human Development Report, (2019), hdr.undp.org/en/content/human-developmentreport-2019

[18]Dina Shehayeb , (2011), Crime Prevention and Urban Development - The Case of Greater Cairo , In book: Practical Approaches to Urban Crime Prevention, pp.59 - 78 https://papers.ssrn.com/sol3/papers.cfm?abstract $\mathrm{id}=3163448$ 


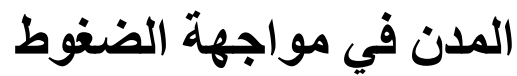 \\ حالة دراسة حي مدينة نصر بالة الماهرة}

يعتبر التحضر السريع أحد سمات نمو السكان في القرن الماضي والحالي. حيث تشير الإحصاءات أن · V مليون شخص سينتقلون للإقامة في المدن سنويا خلال

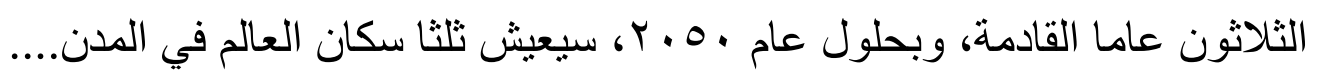

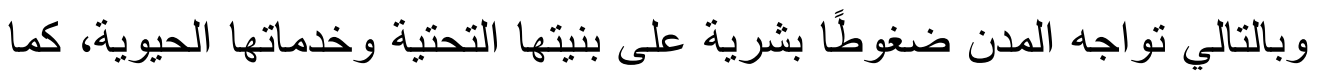

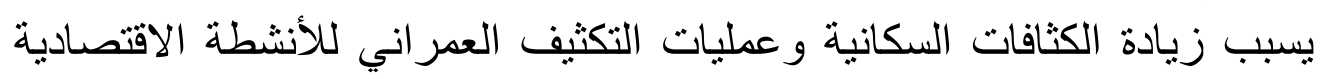
تغير ات ملحوظة في المناخ، مما يؤدي إلى تفاقم التحديات الاجتماعية و الاقتصادية

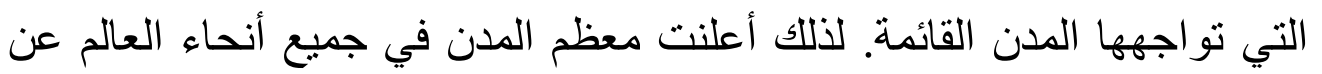

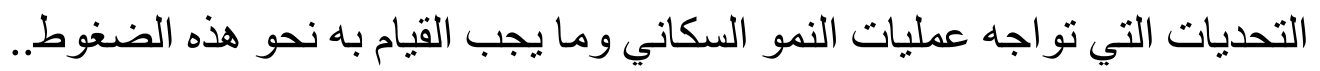

$$
\text { وبالتالي قام البحث: }
$$

(1) عرض وتحليل ظاهرة "المدن تحت الضغط" من كافة الجو انب و التأثير السلبي لتلك التغير ات على جودة الحياة.

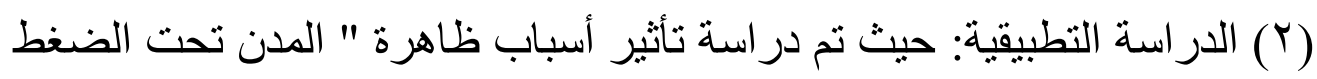

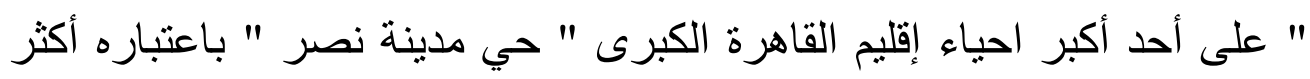
الأحياء الذي يشهد تغييرات حضرية ونمو سكاني بشكل مستمر، ويخضع لئع لكافة

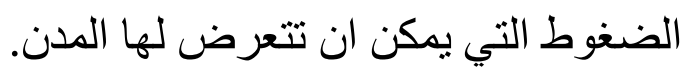
ويهدف البحث إلى وضع رؤية استر اتيجيه متكاملة بخطط تنفيذية لمو اجهة الضغوط لمنان الحالية والحد من أثنار ها المستقبلية بما يرفع من مستوى جودة الحياة ويساعد الاحياء القائمة على المضي نحو الاستدامة. الكلمات المفتاحية: المدن الواقعة تحت الضغط ــ التحضر ــ مدينة نصر - النمو السكاني. 